
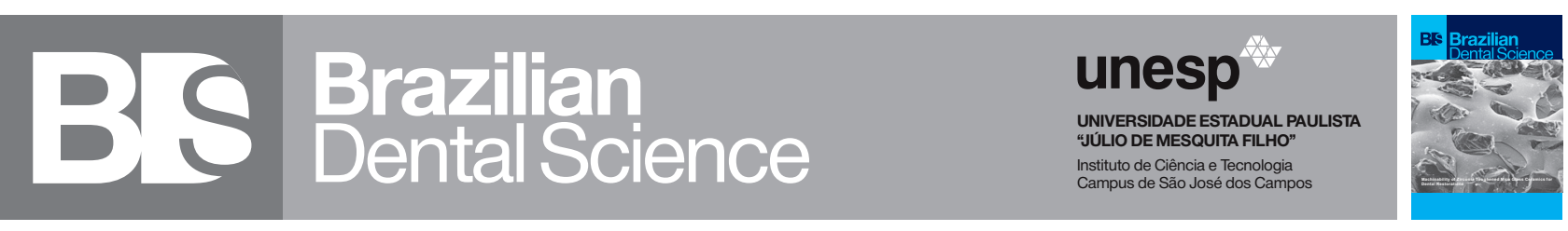

\title{
Comparison of total antioxidant capacity of saliva in men based on daily cigarette consumption
}

Comparação da capacidade antioxidante total da saliva em homens com base no consumo diário de cigarros

Pourya PASHAEI ${ }^{1}$, Zahra ALIZADEH ${ }^{2}$, Hossein PIRI $^{3}$, Monirsadat MIRZADEH ${ }^{4}$, Fatemeh KAZEMI ${ }^{5}$

1 - General Dentist, Student Research Committee, Qazvin University of Medical Sciences, Qazvin, Iran.

2 - Assistant Professor, Department of Oral and Maxillofacial Medicine, Dental Caries Prevention Research Center, Qazvin University of Medical Sciences, Qazvin, Iran.

3 - Associate Professor, Cellular and Molecular Research Center, Qazvin University of Medical Sciences, Qazvin, Iran.

4 - Assistant Professor Community Medicine, Metabolic Diseases Research Center, Research Institute For Prevention Of Non-Communicable Diseases, Qazvin University Of Medical Sciences, Qazvin, Iran.

5 - Student Research Committee, Qazvin University of Medical Sciences, Qazvin, Iran.

\begin{abstract}
Objectives: Antioxidants play an important role in neutralizing of destructive effects of free oxygen and nitrogen radicals. There are contradictory results regarding the relationship between cigarette smoking and total antioxidant capacity of saliva. In this study, the total antioxidant capacity of saliva has been compared in normal smokers, heavy smokers and non-smokers. Material and methods: In this crosssectional study, 28 heavy male smokers (more than one pack of cigarettes per day), 28 normal male smokers (less than one pack of cigarettes per day), and 28 male non-smokers aged 25 to 40 years old entered the study. Unstimulated saliva was collected by Spitting method. The total antioxidant capacity of saliva was measured using Ferric Reducing Antioxidant Power Assay. Descriptive statistics, ANOVA, and Tukey tests were used to analyze the data. Results: The mean total antioxidant capacity of saliva in male non-smokers was $0.0598 \pm 0.08 \mu \mathrm{mol} / \mathrm{L}$, in normal male smokers was $0.049 \pm 0.04 \mu \mathrm{mol} / \mathrm{L}$, and in heavy male smokers was $0.0388 \pm 0.035 \mu \mathrm{mol} / \mathrm{L}$, which did not show any significant difference between the groups (P > 0.05). Conclusion: The results of this study indicate that smoking does not have a significant effect on total antioxidant capacity of saliva in smokers.
\end{abstract}

\section{KEYWORDS}

Smokers; Saliva; Total antioxidant capacity.

\section{RESUMO}

Objetivos: Os antioxidantes desempenham um papel importante na neutralização dos efeitos destrutivos do oxigênio livre e dos radicais de nitrogênio. Existem resultados contraditórios entre a relação do tabagismo e a capacidade antioxidante total da saliva. Neste estudo, a capacidade antioxidante total da saliva foi comparada em fumantes normais, fumantes pesados e não fumantes. Material e métodos: Neste estudo transversal, 28 fumantes pesados (mais de um maço de cigarros por dia), 28 fumantes normais (menos de um maço de cigarros por dia) e 28 homens não fumantes com idade entre 25 e 40 anos de idade foram incluídos no estudo. A saliva não estimulada foi coletada pelo método Spitting. A capacidade antioxidante total da saliva foi medida usando o ensaio de poder antioxidante redutor férrico. Estatística descritiva, ANOVA e testes de Tukey foram usados para analise dos dados. Resultados: A capacidade antioxidante total média da saliva em não fumantes do sexo masculino foi de $0,0598 \pm 0,08 \mu \mathrm{mol} / \mathrm{L}$, em fumantes normais do sexo masculino foi de $0,049 \pm 0,04 \mu \mathrm{mol} / \mathrm{L}$, e em fumantes pesados do sexo masculino foi de $0,0388 \pm 0,035$ $\mu \mathrm{mol} / \mathrm{L}$, e não foi observada diferença significativa entre os grupos $(P>0,05)$. Conclusão: Os resultados deste estudo indicaram que o tabagismo não tem efeito significativo na capacidade antioxidante total da saliva em fumantes.

\section{PALAVRAS-CHAVE}

Fumantes; Saliva; Capacidade antioxidante total. 


\section{INTRODUCTION}

$\mathrm{W}$ ith its antibody, antibacterial agents and antioxidant defense system, saliva acts as the first line of defense for the body. Other saliva functions include the initial digestion of sugar content with the help of amylase and keeping the oral mucosa moisturized, which facilitates the talking and chewing processes [1].

The antioxidant defense system includes compounds that are able to protect biological systems against the harmful effects of free radicals of oxygen and nitrogen, Indeed, antioxidants play an important role in inhibiting of their destructive effects [2].

Antioxidants in the saliva include enzymes such as catalase, glutathione peroxidase, superoxide dismutase, and small molecules such as ascorbate and vitamin E, and proteins such as albumin and transferrin. The total antioxidant capacity is defined as a combination of these compounds [3].

The importance of saliva, as a diagnostic fluid, has become more prominent in recent years, and monitoring salivary markers instead of serum has advantages such as easy access and non-invasiveness, and the close relationship between salivary parameters and serum levels, which has increased the significance of saliva for researchers as a unique fluid in the diagnosis of various diseases over the past two decades [4].

It has been shown that imbalance in the level of free radicals and oxygen species plays a key role in the onset and development of oral inflammation [5]. Smoking, as one of the most important causes of disease and mortality, can be prevented. Cigarette smoke contains a lot of toxins that are immediately absorbed by soft tissue at entrance [6]. In addition, cigarette smoke is a major source of free radicals that has harmful effects on oral health and plays the most important role in cancerous and precancerous lesions and periodontal diseases [7].
Free radicals are atoms or molecules that are highly reactive because of the existence of single electrons in the body and cause a lot of damage to the macromolecules of the body, such as DNA, proteins, lipids, and carbohydrates. Antioxidants deal with the destructive effects of free radicals and maintain the structure and integrity of the tissue $[8,9]$.

Few studies have been conducted on the effect of cigarette on total antioxidant capacity of saliva.

In the study of Falsafi et al. [10], in which the antioxidant capacity of smokers and nonsmokers was examined, there was a significant difference, which was more among nonsmokers. The study by Eizadi et al. [11] showed that total antioxidant capacity in smokers was significantly higher than non-smokers. Abdolsamadi et al. [12] showed that the levels of superoxide dismutase, glutathione peroxidase and peroxidase in smokers were significantly lower than non-smokers, but there was no significant difference in the level of salivary uric acid between smokers and non-smokers.

Considering the controversial results of the few available studies and considering that no study examined the effect of cigarette smoking on total antioxidant capacity, the present study was conducted to compare the total antioxidant capacity of saliva in men based on daily consumption.

\section{MATERIAL AND METHODS}

In this cross-sectional study that was approved by the Ethics Committee of Qazvin University of Medical Sciences, Iran, the statistical population included: 28 heavy male smokers (more than one pack of cigarettes per day over the last five years), 28 normal male smokers (less than one pack of cigarettes per day over the last five years) [9], and 28 male nonsmokers aged 25 to 40 years old who referred 
to Faculty of Dentistry of Qazvin University of Medical Sciences, Iran who were included after obtaining informed written consent. The exclusion criteria were:

1. Inappropriate periodontal condition according to Ramfjord standard with moderate to severe periodontal disease.

2. Inappropriate oral hygiene with a plaque index of over $25 \%$.

3. Having systemic diseases, such as diabetes, high blood pressure and thyroid and sjogren syndrome.

4. The use of drug and food supplements, such as antihypertensive drugs, anti-allergens, and vitamins.

5. People who were passively exposed to cigarette smoke.

6. People who used to smoked and quit.

\section{Sampling method}

Unstimulated saliva was collected by Spitting method according to Navazesh (The patients did not eat, drink or smoke for 90 minutes before collecting saliva and the saliva was collected in a sitting position. The patients were asked to maintain their saliva in the mouth for one minute and then pour it in sterilized Falcon tube and repeat this process for five minutes. All specimens were collected after an overnight fast between 8:00 and 12:00 in the morning. All participants refrained from any severe physical activity $48 \mathrm{~h}$ before measurements and then fasting blood samples transferred to the freezer in a short time (under 5 minutes) and stored at $-20^{\circ} \mathrm{C}$.

\section{Experimental Method}

Samples were centrifuged for 10 minutes after de-freezing at a speed of $4000 \mathrm{rpm}$ to obtain homogenized and clarified specimens. The whole germs and cells were separated in this step.
The total antioxidant capacity of saliva was measured in vitro by FRAP (Ferric Reducing Antioxidant Power) method using a complete antioxidant capacity kit (ZellBio, Germany).

This kit provides a simple, standard, repeatable method for measuring total antioxidant capacity in biological samples such as serum, plasma, saliva, urine, homogeneous tissue, cell culture, and other physiological samples. This method is based on the serum's ability in reduction of ferric into ferrous ions. Then in the presence of tripyridyltriazine (TPTZ), ferrous ions form the Fe2+-TPTZ blue complex, with a maximum absorption wavelength of 593 nm.

The antioxidant power of serum can be measured by considering the amount of concentration increase of the above-mentioned complex using spectrophotometer. Different concentrations of ferrous sulfate (FeSO4) were used as standard.

For each antioxidant power measurement, two tubes were used for the sample and standard and one extra tube was used for the blank sample. Into each of them, $1.5 \mathrm{ml}$ of the ready-to-use solution, including $25 \mathrm{ml}$ of acetate buffer, $2.5 \mathrm{ml}$ of TPTZ solution and $2.5 \mathrm{ml}$ of $\mathrm{FeCl} 3.6 \mathrm{H} 2 \mathrm{O}$ solution was added and maintained at $37^{\circ} \mathrm{C}$ for 5 minutes. $50 \mu \mathrm{l}$ of serum, $50 \mu \mathrm{l}$ of the standard solution and $50 \mu \mathrm{l}$ of distilled water were added into the sample, standard and blank tubes, respectively. After 5 minutes at laboratory temperature, the absorbance of the samples and the standard were read at $593 \mathrm{~nm}$ against the blank and then the concentrations of antioxidants in the samples were determined using the standard curve.

Data were analyzed using SPSS21 statistical software. Descriptive statistics, ANOVA, and Tukey tests were used to analyze the data. 


\section{RESULTS}

A total of 84 qualified candidates participated in this study, all of whom were male. The mean age of participants was 30.42 \pm 4.8 years in heavy smokers group, $30.85 \pm$ 4.33 years in normal smokers group, and $31.5 \pm$ 5.64 years in non-smokers group. There was no significant difference in age group between the three groups ( $\mathrm{p}$-value $=0.72$ )

The mean total antioxidant capacity of saliva in non-smokers was $0.0598 \pm 0.08 \mu \mathrm{mol}$ / $\mathrm{L}$, and the minimum and maximum values were 0.012 and $0.435 \mu \mathrm{mol} / \mathrm{L}$, respectively. The mean total antioxidant capacity of saliva in normal smokers was $0.049 \pm 0.04 \mu \mathrm{mol} / \mathrm{L}$, and its maximum and minimum values were 0.008 and $0.205 \mu \mathrm{mol} / \mathrm{L}$, respectively. The mean total antioxidant capacity of saliva in heavy smokers was $0.0388 \pm 0.035 \mu \mathrm{mol} / \mathrm{L}$, and the maximum and minimum values were 0.007 and $0.129 \mu \mathrm{mol} / \mathrm{L}$, respectively. The highest total antioxidant capacity of saliva was found in non-smokers and the lowest was found in heavy smokers.

In One-Way ANOVA, the groups were compared in terms of total antioxidant capacity and there was no significant difference between the groups $(\mathrm{p}=0.41)$.

Table I shows total antioxidant capacity of studied subjects and Table II shows comparison Mean level of total antioxidant capacity of three groups by Tokey method.

Table I - total antioxidant capacity of studied subjects (mM)

\begin{tabular}{ccccc} 
Sample & Mean & $\begin{array}{c}\text { Standard } \\
\text { Deviation }\end{array}$ & Minimum & Maximum \\
\hline Non smoker & 0.0598 & 0.08 & 0.012 & 0.435 \\
Normal smoker & 0.049 & 0.04 & 0.008 & 0.205 \\
\hline heavy smokers & 0.0388 & 0.035 & 0.007 & 0.129 \\
\hline
\end{tabular}

Table II - Comparison of Mean level of total antioxidant capacity of three groups by Tokey method

\begin{tabular}{|ccc|}
\hline Comparison & Mean difference & P. Value \\
\hline Nonsmokers with smokers & 0.0107 & 0.493 \\
\hline $\begin{array}{c}\text { Nonsmokers with heavy smokers } \\
\text { Normal smokers with heavy } \\
\text { smokers }\end{array}$ & 0.0209 & 0.183 \\
\hline $\begin{array}{c}\text { s. } \\
\text { s. }\end{array}$ & 0.0102 & 0.515 \\
\hline
\end{tabular}

\section{DISCUSSION}

Cigarette smoke is a mixture of chemicals containing over 4000 components same as nicotine, ammonia, acrolein, phenols, benzopyrine, carbon monoxide, polonium, radium. In addition, it contains free radicals that can cause cellular damage. There is relationship between DNA damage and free radicals. [12]

Saliva is fluid containing water, organic and inorganic components, which is produced by the major and minor salivary glands. It also contains cytokines, buffers, immunoglobulins, enzymes, growth factors, Mosin and other host glycoproteins as well as defense systems such as antioxidant defense system that serves as the first line of defense against oxidative stress. [10]

In the present study, reduction of total antioxidant capacity was observed in two groups of normal smokers and heavy smokers, compared to non-smokers, but this difference was not significant. Similar studies indicated contradictory results. Results consistent with the results of this study, such as the study by Motlabnejad et al. [13] to determine the total antioxidant capacity of saliva and serum in mice exposed to cigarette smoke, the total antioxidant capacity in the group exposed to cigarette smoke was compared with control group, and did not show any significant difference on the 30th day. Charalabopoulos et al. [14] showed that despite the increase in antioxidant levels of plasma in smokers, the total antioxidant capacity of saliva in the two groups was not different. Similar to the study of Guentsch et al. [15], there was a significant difference in total antioxidant 
capacity of saliva between smokers and nonsmokers in the study of Buduneli et al. [16].

The result of the study of Eizadi et al. [11] were not consistent with the results of this study. In their study on the total antioxidant capacity in 16 adult male smokers and 16 male nonsmokers, total antioxidant capacity in smokers was significantly higher than non-smokers, which can be due to fewer samples in this study, different population, genetics and nutrition of the subjects, as well as differences in saliva collection method and measurement of the total antioxidant capacity.

According to a study by Arbabi-Kalati et al. [17], smoking can reduce the total antioxidant capacity of the saliva.

In the study of Greabu et al. [18], total antioxidant capacity of saliva in smokers was lower than that of non-smokers. In the study of Fujinami et al., peroxidase and total saliva protein activity in mice exposed to cigarette smoke was lower than other mice [17].

Different factors are effective in increasing or decreasing total antioxidant capacity, which can be related to the type of nutrition of the participants, genetics, climate of the place of residence, as well as the age and gender of the participants under study. On the other hand, the saliva contains an enzymatic and non-enzymatic antioxidant system. Non-enzymatic antioxidants include uric acid, $\alpha$-tocopherol, flavonoids, albumin, ascorbic acid, glutathione, $\beta$-carotene and other compounds. Enzymatic antioxidants include superoxide dismutase, glutathione peroxidase and catalase [18,19]. Cigarette smoking increases some of these antioxidants and reduces some of them, and it has no effect on some antioxidants.

Considering that in the present study, saliva was collected when patients did not consume cigarettes, it may seem that smoking can affect the salivary gland and its antioxidant production over time.
In the present study, total antioxidant capacity was lower in the smokers group; the higher the daily consumption (heavy smokers), the smaller this value, though there was no significant difference between heavy smokers, normal smokers and non-smokers. Of course, due to the small number of samples and the non-significant results of the study, we cannot generalize this result. In addition, total salivary antioxidant changes in terms of cigarette consumption rate were not evaluated in other studies and comparing this part with other studies was not possible.

\section{CONCLUSION}

The purpose of this study was to measure the salivary total antioxidant capacity in smoker and nonsmoker patients (in variety amount of cigarette).The result of this study showed that cigarette smoke is associated with decrease in total antioxidant capacity, and increase in consumption is associated with more reduction of it, but it's not significant.

More research aimed at test the level of TAC profile in smokers should be considered

\section{Conflict of interest}

None

\section{Funding sources}

None

\section{REFERENCES}

1. Tenovuo J. Antimicrobial agents in saliva--protection for the whole body. J Dent Res. 2002Dec;81(12):807-9.

2. Cochrane CG. Cellular injury by oxidants. Am J Med. 1991 Sep 30;91(3C):23S$30 \mathrm{~S}$.

3. Battino M, Ferreiro MS, Gallardo I, Newman HN, Bullon P. The antioxidant capacity of saliva. J Clin Periodontol. 2002 Mar;29(3):189-94.

4. Nagler RM. Saliva analysis for monitoring dialysis and renal function. Clin Chem. 2008 Sep;54(9):1415-7.

5. Pasupathi P,Rao YY,Farook J, Saravanan G, Bakthavathsalam G. Effect of cigarette smoking on lipids and oxidative stress biomarkers in patients with acute myocardial infarction. Res J Med Med Sci. 2009;4:15I-9. 
6. Reznick AZ, Klein I,Eiserich JP,Cross CE, Nagler RM. Inhibition of oral peroxidase activity by cigarette smoke: in vivo and in vitro studies. Free Radic Biol Med. 2003Feb 1;34(3):377-84.

7. Yildiz L, Kayaoğlu N, Aksoy H. The changes of superoxide dismutase, catalase and glutathione peroxidase activities in erythrocytes of active and passive smokers. Clin Chem Lab Med. 2002 Jun;40(6):612-5.

8. Halliwell B. Antioxidant characterization. Methodology and mechanism. Biochem Pharmacol. 1995 May 17;49(10):1341-8.

9. Schane RE, Ling PM, Glantz SA. Health effects of light and intermittent smoking: a review. Circulation. 2010 Apr 6;121(13):1518-22.

10. Falsafi P,Nasrabadi ET,Nasrabadi HT, Khiyavi RK, Eslami H. Comparison of Total Antioxidant Capacity and Vitamin C in smokers and non-smokers. Biomedical and Pharmacology Journal. 2016;9(1):299-304.

11. MojtabaE, Davood K, Hussein D, editors. Lower total antioxidant capacity in smokers compare to non-smokers. Biological Forum. 2014;6(2):305-9.

12. Abdolsamadi HR, Goodarzi MT,Mortazavi H, Robati M, Ahmadi-Motemaye F. Comparison of salivary antioxidants in healthy smoking and non-smoking men. Chang Gung Med J. 2011Nov-Dec;34(6):607-11.

13. Motalebnejad M, Pouramir M, Moghadamnia AA, Ghasemi L, Soleimani L. The effect of passive smoking on total antioxidant capacity of serum and saliva in rats. Shahid Beheshti University Dental Journal. 2013;31(2):117-24.
14. Charalabopoulos K, Assimakopoulos D, Karkabounas S, Danielidis V, Kiortsis D, Evangelou A. Effects of cigarette smoking on the antioxidant defence in young healthy male volunteers. International journal of clinical practice. 2005;59(1):25-30.

15. Guentsch A, Preshaw PM, Bremer-Streck S, Klinger G, Glockmann E, Sigusch BW. Lipid peroxidation and antioxidant activity in saliva of periodontitis patients: effect of smoking and periodontal treatment. Clin Oral Investig. 2008 Dec;12(4):345-52

16. Buduneli N, Kardeşler L, Işik H, Willis CS, Hawkins SI, Kinane DF, etal. Effects of smoking and gingival inflammation on salivary antioxidant capacity. JClin Periodontol. 2006 Mar;33(3):159-64.

17. Arbabi-Kalati F,Nosratzehi T,Salimi S, Sadeghi Sabzevari R, Arbabi-Kalati P.Comparison of total antioxidant capacity of saliva in smokers and nonsmokers. Journal of Mashhad Dental School. 2014;38(2):93-8.

18. Greabu M, Didilescu A, Puiu L, Miricescu D, Totan A. Salivary antioxidant biomarkers in non-ferrous metals mine workers--a pilot study. J Oral Pathol Med. 2012 Jul;:41(6):490-3.

19. Dodwad R, Betigeri AV, Preeti BP.Estimation of total antioxidant capacity levels in saliva of caries-free and caries-active children. Contemp Clin Dent. 2011 Jan;(1):17-20.

\section{Zahra Alizadeh}

(Corresponding address)

Dental Caries Prevention Research Center, Qazvin University of Medical Sciences, Bahonar Blvd., Qazvin, Iran.

Email: z.alizadeh@qums.ac.ir

Date submitted: 2020 Jun 01

Accept submission: 2020 Aug 18 